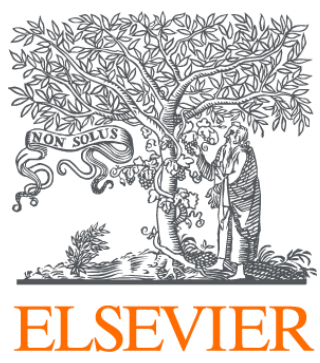

Since January 2020 Elsevier has created a COVID-19 resource centre with free information in English and Mandarin on the novel coronavirus COVID-

19. The COVID-19 resource centre is hosted on Elsevier Connect, the company's public news and information website.

Elsevier hereby grants permission to make all its COVID-19-related research that is available on the COVID-19 resource centre - including this research content - immediately available in PubMed Central and other publicly funded repositories, such as the WHO COVID database with rights for unrestricted research re-use and analyses in any form or by any means with acknowledgement of the original source. These permissions are granted for free by Elsevier for as long as the COVID-19 resource centre remains active. 
the contents before sampling, avoiding sampling only from the top layer. A control experiment with parafilm on non-crystal glass was also done. The evaporative effect could be significant because an impressive number of droplets accumulated on the underside of the parafilm. The evaporative effect should not be countered by asserting that it would also happen during the drinking of wine at the table. Evaporation only increases the concentration but not the amount of lead actually ingested.

I am concerned that press reports of Graziano and Blum's findings have led to unnecessary public concern about drinking from lead crystal, a practice the more affluent have done for decades with apparent impunity. They quote US Enviromental Protection Agency allowable limits for drinking water of $50 \mu \mathrm{g} / \mathrm{l}$ with a possible reduction to $20 \mu \mathrm{g} / 1$. Some wines used in their study were above the $20 \mu \mathrm{g} / \mathrm{l}$ at the start of the study. The level of increase seen in the glass leaching experiment (if not due to evaporation) could fade to insignificance beside the drinking of wine with a higher starting lead content. Wine is unlikely to be a important source of lead unless a lot is consumed, ${ }^{2}$ which is not the case if it is left in a glass for up to 4 hours.

Mater Miserıcordiae Publıc Hospital,

Brisbane 4000, Queesnsland, Australia

E. DE LEACY

1. De Leacy EA. Lead crystal decanters: a health rise? Med f Aust 1987; 147: 622.

2. Elias RW. Lead exposure in the environment. In: Mahaffey KR, ed. Dietary and environmental lead: human health effects. New York: Elsevier, 1985: 79-107.

\section{Diagnosis of torovirus infection}

SIR,--In 1984, Beards and colleagues reported the appearance of torovirus-like particles in stools of patients with diarrhoea. ${ }^{1}$ Toroviruses are enveloped, positive-stranded RNA viruses that cause enteric infections in animals-eg, horses (Berne virus, BEV) ${ }^{2}$ and cattle (Breda virus, BRV). ${ }^{3}$ A human sample was reported to agglutinate rat erythrocytes, and the reaction was inhibited by antisera from calves experimentally infected with BRV. ${ }^{4}$ Diagnostic techniques to detect toroviruses in clinical specimens include haemagglutination (HA) and haemagglutination-inhibition tests (HA/HI), enzyme-linked immunosorbent assay (ELISA), immune electronmicroscopy, and nucleic acid hybridisation. Direct electronmicroscopy of negatively-stained faeces is not reliable for diagnosis because of the pleomorphic appearance of toroviruses and their morphological resemblance with coronaviruses.

Antibodies have not been detected with BEV neutralisation tests and BRV EL ISA in sera from human beings. ${ }^{5,6}$ We have recently found torovirus antibodies in 13 members of one family in France (sera provided by H. J. van Kruiningen, University of Connecticut) with a history of enteric disease (unpublished). Most human toroviruses are probably only distantly related to BEV or BRV, and molecular detection techniques were thought more promising than serological assays. We completed hybridisation assays with cDNA probes against $\mathrm{BEV}$ for the diagnosis of torovirus infection in man.

Faeces from 5 adults and 73 babies (samples from Dr F. Lamouliatte, Bordeaux, France) with diarrhoea, in which

CONTROL RNA Poly (A)

\section{FAECES} (Humans)
BEV

MHV

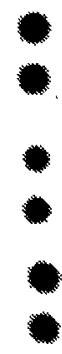

torovirus-like particles had been observed by electronmicroscopy, were studied. They had been stored for over four years at $-20^{\circ} \mathrm{C}$. In addition, 39 fresh samples were tested. RNA was extracted from stools with $6 \mathrm{~mol} / 1$ guanidine isothiocyanate and adsorbed to size-fractionated silica particles. Intracellular poly (A)-selected RNAs from cells infected with BEV or mouse hepatitis virus (MHV), a coronavirus, served as positive and negative controls (figure). BEV cDNA clones that covered the structural protein genes and part of the polymerase protein gene were used as probes.

Of 78 specimens stored at $-20^{\circ} \mathrm{C}, 8$ gave weak positive hybridisation reactions (figure). Strong hybridisation signals were obtained with 3 of the 39 fresh faecal samples (figure). None of these results could be confirmed by ELISA. In HA tests with rat and human group $\mathrm{O}$ erythrocytes, low HA titres were found (below 64) that were not reduced by anti-BRV serum.

The detection of RNA extracted from BEV-infected culture supernatants can be increased from a minimum of $10^{5}$ median tissue culture infective dose units to $10^{2}$ units with the aid of the polymerase chain reaction; this technique was used to confirm hybridisation results. Successful amplification was achieved with a set of primers homologous to the $3^{\prime}$ ends of BEV and BRV RNA on nucleic acid extracted from two of the three hybridisation-positive human stools. These preliminary results suggest a high degree of sequence similarity between the 3 ' ends of genomic RNA from human, bovine, and equine toroviruses.

Institute of Infectious

Diseases and Immunology,

Department of Virology,

Veterinary Faculty,

State University of Utrecht

$3584 \mathrm{CL}$ Utrecht, Netherlands

MARION KOOPMANS ARNOLD HERREWEGH MARIAN C. HORZINEK

1. Beards GM, Green J, Hall C, Flewett TH, Lamouliatte F, du Pasquier P. An enveloped virus in stools of children and adults with gastroenteritis that resembles the Breda virus of calves. Lancet 1984; ii: 1050-52.

2. Weiss $M$, Steck $F$, Horzinek MC. Purification and partial characterization of a new enveloped RNA virus (Beme virus). F Gen Virol 1983; 64: 1849-58.

3. Woode GN, Reed DE, Runnels PL, Herrig MA, Hill HT. Studies with an unclassified virus isolated from diarrheic calves. Vet Microbiol 1982; 7: 221-40.

4. Beards GM, Brown DWG, Green J, Flewett TH. Preliminary characterization of torovirus-like particles of humans: comparison with Berne virus of horses and Breda virus of calves. $\mathcal{F}$ Med Virol 1986; 20: 67-68.

5. Weiss M, Steck F, Kaderli R, Horzinek MC. Antibodies to Berne virus in horses and other animals. Vet Microbiol 1984; 9: 523-31.

6. Brown DWG, Beards GM, Flewett TH. Detection of Breda virus antigen and antibody in humans and animals by enzyme immunoassay. $f$ Clin Microbiol 1987; 25: $637-40$.

\section{Anaphylactic reaction to ampicillin and severe complication in the fetus}

SIR,-Anaphylaxis is a fairly uncommon event in pregnancy that can have serious implications for both mother and fetus. Several central nervous system damage in the preterm fetus and death in infancy have been attributed to maternal hypotensive anaphylaxis whereas at term the fetus has been regarded as protected. ${ }^{1-3} \mathrm{~A}$ case of severe anaphylaxis to ampicillin during labour with good fetal outcome has lately been described. ${ }^{4}$ We report a severe fetal complication after intravenous application of ampicillin to a woman at term.

A 42-year-old woman, gravida 4, para 2, was admitted with premature rupture of membranes at $\mathbf{4 0}$ weeks' gestation. Since cervix score was low and no uterine contractions were noted we decided to wait until spontaneous onset of labour. Prophylactic antibiotic therapy with $2 \mathrm{~g}$ of ampicillin was prescribed to prevent intra-amniotic infection. 5 minutes after administration the patient complained of itching, burning, and nausea associated with pronounced skin flushing and a fall in blood pressure from 130/70 to $85 / 50 \mathrm{~mm} \mathrm{Hg}$. She received glucocorticoids, calcium, and antihistamines and recovered immediately. Fetal heart rate was monitored after this reaction and a smooth sine wave-line baseline with a frequency of about 100 beats per minute was seen. Concomitantly the onset of uterine contractions began and tocolytic therapy was therefore initiated and caesarean section was done. A male infant weighing $3150 \mathrm{~g}$ was delivered, with Apgar scores of 3, 6 , and 7 at 1,5 , and 10 minutes, respectively, and severe metabolic acidosis (arterial cord blood pH 6.71). He was intubated and 